\title{
Biological and biogeochemical effects of organic matter and drilling discharges in two sediment communities
}

\author{
Hilde C. Trannum ${ }^{1, *}$, Hans C. Nilsson ${ }^{1,2}$, Morten T. Schaanning ${ }^{1}$, Karl Norling ${ }^{1,3}$ \\ ${ }^{1}$ Norwegian Institute for Water Research (NIVA), Gaustadalléen 21, 0349 Oslo, Norway \\ ${ }^{2}$ Department of Aquatic Resources, Swedish University of Agricultural Sciences, Turistgatan 5, 45330 Lysekil, Sweden \\ ${ }^{3}$ Department of Biology, University of Oslo, PO Box 1066 Blindern, 0316 Oslo, Norway
}

\begin{abstract}
The present study investigates the relation between community characteristics, input of organic matter and drill cuttings. Drill cuttings are discharged from offshore oil and gas exploration, and settle on soft bottom sediments where the benthic fauna may be affected. In a 3factorial mesocosm experiment, 2 benthic communities were treated with either water-based drill cuttings or natural sediment in combination with addition or no addition of organic matter, and biochemical and biological responses were studied. The biogeochemical response of organic matter and drill cuttings additions resembled each other, in both cases resulting in enhanced sediment-water fluxes of oxygen, nitrate and ammonium, and reduced concentration of oxygen in sediment pore water. This finding indicated degradation of an organic compound in the water-based drill cuttings. Regarding the biological response, benthic community composition was significantly different for all treatment factors, evidenced by PERMANOVA. Abundance and biomass were reduced in boxes without addition of organic matter, probably as a response to starvation, while abundance and taxa richness were reduced in boxes with drill cuttings. The particular effect of water-based drill cuttings on the environment seems to be complex, and should be investigated further.
\end{abstract}

KEY WORDS: Benthos · Biogeochemical fluxes · Oil exploration · Organic matter · Oxygen microdistributions $\cdot$ Water-based drilling mud

\section{INTRODUCTION}

Benthic communities are important for marine ecosystem processes as the benthic organisms alter the physical and chemical conditions at the sediment-water interface, promote decomposition of organic matter, recycle nutrients for photosynthesis, and transfer energy to other food-web components (Gray 1974, Aller 1982, Gaston et al. 1998, Lohrer et al. 2004). Benthic organisms have close contact with sediment-particles and interstitial water for a great part of their lives, and are therefore particularly vulnerable to sediment contamination (Traun- spurger \& Drews 1996). Since the organisms are mostly sessile, they integrate long term effects of environmental change over time (Gray et al. 1990). Benthic fauna has therefore been used in environmental monitoring for almost a century, and is considered a highly relevant and sensitive proxy for measuring anthropogenic influences (e.g. Gray \& Elliott 2009).

Drilling discharges from offshore oil and gas installations affect benthic fauna through various factors, e.g. hypoxia, toxicity, sedimentation or change in particle properties like grain size and sharpness (Singsaas et al. 2008). Because of severe environ- 
mental impacts around drilling installations using oilbased and synthetic muds (e.g. Kingston 1987, Neff et al. 1987, Gray et al. 1990, Olsgard \& Gray 1995, Daan \& Mulder 1996), the use of water-based drilling muds has increased and is currently considered the less environmentally harmful alternative. Waterbased drill cuttings (crushed bed rock mixed with drilling muds) have been considered to have minor or no negative impact on the marine environment except burial (e.g. Hyland et al. 1994, Currie \& Isaacs 2005, Netto et al. 2010). However, recent studies have indicated that the effects may be more severe than previously assumed, and that impact factors other than burial trigger the response (Schaanning et al. 2008, Trannum et al. 2010). In light of possible expansion of drilling activities to pristine areas further north and in more coastal, shallow areas, we need to increase our knowledge of the generality of benthic responses.

Benthic community composition varies across all spatial scales, but common environmental drivers include sediment characteristics, depth, input of organic matter and temperature (e.g. Gray 1974, Rhoads 1974, Grebmeier et al. 1988, Etter \& Grassle 1992, Ambrose \& Renaud 1995, Ellingsen 2002, Quijón et al. 2008, Li et al. 2009). A general problem in ecological monitoring is the differentiation of anthropogenic-induced changes from the natural variations constantly occurring in marine communities (Christie 1985). Moreover, such inherent variation may interact with anthropogenic disturbances (Thrush et al. 2008, Lohrer et al. 2010, Svensson et al. 2010), which makes it more difficult to predict environmental responses.

Both sediment properties and organic matter are important for bioavailability of contaminants (Swartz et al. 1986, Kemp 1988, Green et al. 1993, Gunnarsson et al. 1996, 1999, Maloney 1996, Granberg and Selck 2007). Regarding sediment properties, several studies have documented more severe effects of heavy metals on fauna in coarse than in fine sediments (Pesch 1979, Tietjen 1980, Austen \& McEvoy 1997, Trannum et al. 2004), which also seems to apply for metals in sediments contaminated with oilbased and synthetic based drill cuttings (Grung et al. 2005). However until now, no relation has been established between the effects of water-based drill cuttings and variations in organic matter regime and sediment community.

The present work addresses the relation between community characteristics, input of organic matter and drilling discharges. By using an experimental approach, this study investigates 3 questions:
- What are the effects of water-based drill cuttings in benthic communities?

- What are the effects of organic matter in benthic communities?

- What is the relation between the factors community, organic matter and water-based drill cuttings?

Biological effects were quantified by macrofaunal community composition, species richness, abundance, and biomass. Biogeochemical responses measured were sediment-water fluxes of oxygen, nitrate and ammonium and sediment oxygen microdistributions.

\section{MATERIALS AND METHODS}

\section{Experimental design}

The experiment was carried out on box core samples of fine and coarse sediments installed in a mesocosm facility in SE Norway. It was designed as a full factorial experiment with the 3 fixed factors:

(1) Community, with the 2 levels fine (FI) or coarse (CO)

(2) Organic matter, with the 2 levels organic matter addition (OM) or no addition (NO)

(3) Capping material, with the 2 levels water-based drill cuttings (WB) or natural test sediment (TS)

With 3 replicates, the experiment had 24 boxes with 8 different treatments; CO-OM-TS, CO-OMWB, CO-NO-TS, CO-NO-WB, FI-OM-TS, FI-OMWB, FI-NO-TS, FI-NO-WB (see e.g. Table 2). The factor community was inherent in the box core samples, while the factors organic matter and capping material were imposed during setup of the experiment. The factor organic matter included a temperature manipulation of $2^{\circ} \mathrm{C}$, intended to simulate a slight change representative of short-term (seasonal), long-term (climate change) or spatial (offshore compared to nearshore) variation.

\section{Field sampling and experimental set-up}

On 4 and 5 March 2007, 12 box core samples were collected at $96 \mathrm{~m}$ depth (denoted $\mathrm{CO} ; 59.652^{\circ} \mathrm{N}$, $10.621^{\circ} \mathrm{E}$ ) and 12 samples at $116 \mathrm{~m}$ depth (denoted FI; $59.643^{\circ} \mathrm{N}, 10.629^{\circ} \mathrm{E}$ ) with a $0.09 \mathrm{~m}^{2} \mathrm{KC}$ box corer with transparent inner liner in the outer Oslofjord, SE Norway. Within $<8 \mathrm{~h}$, the boxes were installed in 2 water baths, so that each contained $6 \mathrm{CO}$ and 6 FI samples, in the nearby mesocosm facility at Solbergstrand (Berge et al. 1986, Trannum et al. 2010). 
The mesocosm resembles the conditions at the fjord sampling locations as the mesocosm is kept relatively cool and dim and supplied with unfiltered seawater from $60 \mathrm{~m}$ depth, and the benthic communities can be maintained for several months (Schaanning et al. 2008). A lid, which was partly submersed in seawater, covered each box, and a weight was placed on top of the lid. Each box received 14 to $22 \mathrm{l} \mathrm{d}^{-1}$ of water from a common header tank, and the flow rates were calibrated regularly. To avoid stagnation an aquarium pump was installed in the lid of each box, and activated for 1 min every $3 \mathrm{~h}$ throughout the experiment. Regular checks were made to ensure that all pumps were functioning and that there were no signs of sediment resuspension caused by the water movement. The communities were acclimatized to the experimental conditions for 1.5 mo before any manipulation started. On 24 April, cooling of 1 of the water baths (designated NO) started. The mean temperature was reduced and maintained at $7.3 \pm 0.85^{\circ} \mathrm{C}$ in the NO water bath throughout the experiment, compared to the 'ambient' temperature $9.5 \pm 0.42^{\circ} \mathrm{C}$ in the other water bath (designated OM). The 2 water baths in the present study were used under similar conditions in an earlier experiment by Trannum et al. (2010), and no significant differences in either faunal parameters or fluxes were observed between replicate boxes in the water baths.

On Day 1 of the experiment (3 May 2007), WB and TS were added, each to 3 FI-NO, 3 CO-NO, 3 FI-OM and $3 \mathrm{CO}-\mathrm{OM}$ boxes, to an estimated capping layer of $6.5 \mathrm{~mm}$. The cuttings originated from a drilling operation in the Barents Sea where discharge of drill cuttings is prohibited, and were delivered from a land-based deposition plant. The mud used in the drilling operation had polyalkylene glycol as a lubricant. The glycol used here is classified as a 'yellow chemical' in Norway, which means that possible effects are 'environmentally acceptable', but it is not included in the OSPAR List of Preparations Used and Discharged Offshore which Are Considered to Pose Little or No Risk to the Environment (PLONOR) (OSPAR Commission 2008). Ilmenite $\left(\mathrm{FeTiO}_{3}\right)$ was the weighting material in the drill cuttings, but the cuttings additionally contained some barite $\left(\mathrm{BaSO}_{4}\right)$. The natural test sediment was collected in the outer Oslofjord and defaunated by sieving through a $1 \mathrm{~mm}$ sieve before freezing at $-20^{\circ} \mathrm{C}$. Both materials were 1:1 mixed with seawater in a stainless steel mixer. The resulting slurry was poured slowly into the boxwater, ensuring even distribution over the sediment surface. To enable settling of particles, the water exchange was stopped for $24 \mathrm{~h}$. Then, on Day 7, a mixture of 4 marine microalgae (Shellfish Diet $1800 \AA$ ) was added with a syringe to an estimated amount of $4.4 \mathrm{~g} \mathrm{C} \mathrm{m}^{-2}$ to each of the OM boxes. The experiment ran for $106 \mathrm{~d}$ in total and $48 \mathrm{~d}$ after introduction of treatment manipulations at Day 1.

\section{Measurements and calculations}

A standard Clark-type oxygen electrode was used to measure the difference between the concentration of oxygen $\left(\mathrm{O}_{2}\right)$ in the common header tank and the overlying water in each box (see Fig. 4 for sampling times). Samples for nitrate and nitrite $\left(\mathrm{NO}_{3}{ }^{-}+\mathrm{NO}_{2}{ }^{-}\right)$ and ammonium $\left(\mathrm{NH}_{4}{ }^{+}\right)$were collected in the header tank and box water, preserved with $4 \mathrm{M} \mathrm{H}_{2} \mathrm{SO}_{4}$, and analyzed with automatic spectrophotometric methods based on principles described in Grasshoff et al. (1983). Thus, nitrate was reduced to nitrite on copper-coated cadmium at $\mathrm{pH} 8$ to 8.5. Nitrite was then reacted to produce a color-complex adsorbing at $540 \mathrm{~nm}$. Ammonium was reacted with hypochlorite at $\mathrm{pH} 10.8$ to 11.4 to yield a color-complex adsorbing at $630 \mathrm{~nm}$. Nitrite was not determined separately, so the concentrations and fluxes given for nitrate actually represent nitrate + nitrite.

The fluxes $\left(J_{\text {tot }}\right)$ were calculated from the equation:

$$
J_{\text {tot }}=\frac{\left(C_{i}-C_{o}\right) \times Q}{A}
$$

where $C_{\mathrm{i}}=$ concentration in header tank, $C_{0}=$ concentration in box water, $Q$ = flow of water through the box, and $A=$ sediment area of box. $Q$ was measured gravimetrically after collection of outflow water for $4 \mathrm{~min}$. For a more comprehensive description of flux calculations, see Trannum et al. 2010.

Oxygen profiles in the sediments were measured with a Unisense ${ }^{\mathrm{TM}}$ Clark-type microelectrode (OX100) mounted on a motorized micromanipulator attached to a frame that was put on each box, allowing in situ measurements at $250 \mu \mathrm{m}$ depth intervals (Revsbech 1989). Readings were taken from $4 \mathrm{~mm}$ above the sediment surface down to zero oxygen concentrations. These profiles were adjusted to the correct water-sediment interface (using the slope difference when the electrode enters the sediment) and later used to calculate the diffusive flux of oxygen $\left(J_{\text {diff O2 }}\right)$. Calculations of the diffusive flux of oxygen between the overlying water and the surface sediment in each box were performed on oxygen profiles from Day 21 using Fick's first law of diffusion adapted to sediment conditions (Berner 1980): 


$$
J_{\text {diff }}=-\varphi \times D_{\mathrm{s}} \times\left(\frac{\partial C}{\partial z}\right)
$$

where $\varphi=$ the porosity in the top layer $(0$ to $1 \mathrm{~cm}$ ) of the sediment, and $\partial C / \partial z=$ the linear concentration gradient in the surface sediment layer immediately below the sediment surface. The whole sediment diffusion coefficient $\left(D_{\mathrm{s}}\right)$ was calculated from the diffusion coefficient in free solution, $D_{0}$, corrected for temperature, salinity and tortuosity, using the Archie-type relation: $D_{\mathrm{s}} \sim \varphi^{2} \times D_{0}$ (Boudreau 1996). The total amount of dissolved oxygen in the sediment pore water (denoted pore water $\mathrm{O}_{2}$ ) was calculated by integrating the oxygen concentration profile over the sediment depth. While $J_{\text {tot }}$ represents an integrated measure of the diffusive, advective and faunal-mediated $\mathrm{O}_{2}$ consumption, $J_{\text {diff }}$ primarily estimates diffusive processes (Hulth et al. 1994, Glud et al. 2003). Thus the ratio $J_{\text {tot } \mathrm{O} 2}: J_{\text {diff } \mathrm{O} 2}$ quantifies the contribution of biologically mediated transport processes to $J_{\text {tot } \mathrm{O} 2}$.

Analysis of grain size and particle shape was performed on the box-core sediments (CO and FI) and added materials (TS and WB). For analysis of grain size, wet sieving separated the samples into coarse $(>0.063 \mathrm{~mm})$ and fine $(<0.063 \mathrm{~mm})$ fractions. The fine fraction was dried $\left(60^{\circ} \mathrm{C}\right)$, weighed and analyzed in a Sedigraf 5100 which volumetrically determines 7 size fractions. The coarse fraction was oven dried $\left(40^{\circ} \mathrm{C}\right)$, weighed and shaken for $10 \mathrm{~min}$ through a nest of graded sieves $(2,1,0.5,0.25$, 0.125 and $0.063 \mathrm{~mm})$. Median particle size $\phi(\phi=$ $-\log _{2}$ of the particle diameter in $\mathrm{mm}$ ), skewness (distribution pattern around the mean) and kurtosis (peakedness of the distribution curve) were calculated from the size determinations (Buchanan 1971). Particle shape was measured as roundness and convexity. Although these parameters do not describe sharpness directly, they may indicate whether the particles are characterized by sharp edges or not. Roundness is a measurement of the length:width relationship, with values in the range 0 to 1 . A perfect circle has roundness 1.0 and a needle-shaped object has roundness close to 0 . Convexity has values in the range 0 to 1 , where a convex shape has convexity 1.0 and concave shape has a value close to 0 . The analysis was performed with PharmaVision 830, which performs automated analysis using microscopy techniques. Due to methodology restrictions, only particles in the range 5 to $2000 \mu \mathrm{m}$ were analyzed. Almost all sample particles were $<2000 \mu \mathrm{m}$, but a considerable proportion was also $<5 \mu \mathrm{m}(12 \%$ of $\mathrm{WB}, 19 \%$ of
CO, $36 \%$ of FI and $43 \%$ of TS). Microscope images of drill cuttings and natural sediment particles were taken to obtain a visual impression of particle properties.

At the end of the experiment, the sediments were washed through a $0.5 \mathrm{~mm}$ sieve with circular holes for retrieval of macrofauna, preserved with $10 \%$ buffered formalin, and later transferred to 75 to $80 \%$ ethanol. The organisms were identified to species or lowest possible taxonomic level and biomass was determined for the main taxonomic groups.

\section{Statistical analyses}

Three-factor ANOVA was used to analyze number of taxa (S), abundance (A) and biomass of macrofauna, and $J_{\text {tot }}, J_{\text {diff O2 }}$ and $J_{\text {tot O2 }}: J_{\text {diff O2 }}$ for sedimentwater fluxes and $\mathrm{O}_{2}$ concentration in the sediment pore water. The fluxes measured at Days 21 and 47 were selected for statistical testing. Additionally, 2factor ANOVA was conducted for Day 0 to investigate water bath (i.e. temperature) and community effects on the fluxes. Prior to ANOVA, Levene's test was used to check for homoscedasticity (Levene 1960) and normal distributions checked. Some values were then $\log$ transformed. The same statistical design applied to 3-factor ANOVA, was also used in a 3-factor permutational multivariate analysis of variance (PERMANOVA) (Anderson et al. 2008) on the faunal data. PERMANOVA calculated p-values from 9999 permutations based on Bray-Curtis distances (Bray \& Curtis 1957). The same Bray-Curtis matrix was used to perform non-metric multidimensional scaling (MDS). ANOVA was performed with JMP version 6 and the multivariate statistics with PRIMER version 6 and PERMANOVA+ version 1.0.3.

\section{RESULTS}

\section{Visual observations}

After addition of capping material, the sediment surface in the WB boxes was black because of the black ilmenite. During the experiment, burrows and tubes were visible in both WB and TS boxes, and parts of the sediment surface in the WB boxes became brown or grey, indicating upwards sediment mixing by bioturbating animals. Yellow spots appeared on the sediment surface in all WB-OM boxes, in some WB-NO boxes, and in 1 TS-OM box, but in none of the TS-NO boxes. These spots were inter- 
Table 1. Mean grain size $(\phi)$, sediment classification, composition, skewness, kurtosis, mean roundness and mean convexity of box core sediment samples $(\mathrm{CO}=$ coarse, $\mathrm{FI}=$ fine) and capping materials ( $\mathrm{TS}=$ test sediment; $\mathrm{WB}=$ water-based drill cuttings) used in the experiment. For analysis of box core sediments, 1 sample of each sediment type was taken from boxes to which TS was added (i.e. CO-TS and FI-TS boxes). Where means are given, \pm SD represents the variation within the sample.

For particles $<5 \mu \mathrm{m}$, the particle shape was not analyzed

\begin{tabular}{|c|c|c|c|c|c|c|c|c|c|}
\hline & \multirow[t]{2}{*}{$\phi$} & \multirow[t]{2}{*}{ Classification } & \multicolumn{3}{|c|}{ Composition (\%) } & \multirow[t]{2}{*}{ Skewness } & \multirow[t]{2}{*}{ Kurtosis } & \multicolumn{2}{|c|}{ Particle shape } \\
\hline & & & $\begin{array}{c}\text { Pelite } \\
(<0.063 \mathrm{~mm})\end{array}$ & $\begin{array}{c}\text { Sand } \\
(0.063-2 \mathrm{~mm})\end{array}$ & $\begin{array}{c}\text { Gravel } \\
(>2 \mathrm{~mm})\end{array}$ & & & Roundness & Convexity \\
\hline $\mathrm{CO}$ & $3.94 \pm 3.21$ & Fine sand & 39.0 & 59.5 & 1.5 & 0.53 & 0.92 & $0.668 \pm 0.195$ & $0.991 \pm 0.030$ \\
\hline FI & $6.82 \pm 3.28$ & Silt & 57.1 & 43.9 & 0.0 & 0.10 & 0.59 & $0.660 \pm 0.187$ & $0.995 \pm 0.021$ \\
\hline TS & $7.91 \pm 2.69$ & Silt & 88.0 & 12.0 & 0.0 & 0.08 & 0.61 & $0.660 \pm 0.191$ & $0.996 \pm 0.019$ \\
\hline WB & $6.52 \pm 2.73$ & Silt & 74.3 & 23.9 & 1.9 & -0.13 & 1.44 & $0.665 \pm 0.182$ & $0.995 \pm 0.019$ \\
\hline
\end{tabular}

TS

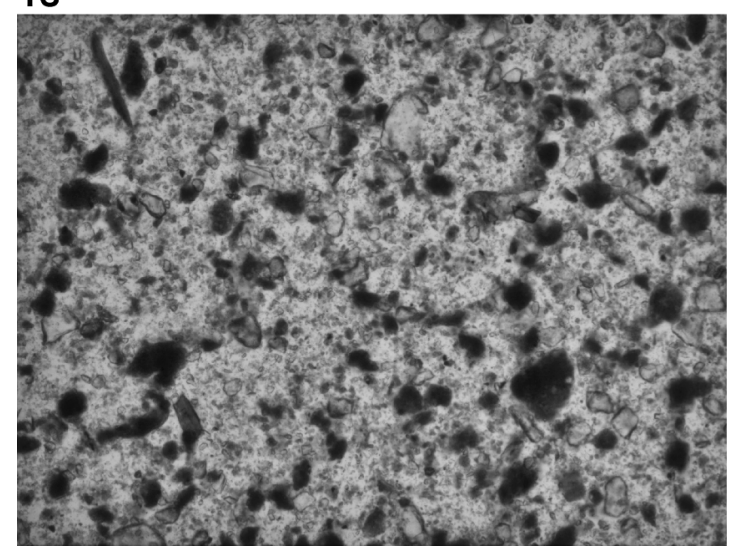

WB

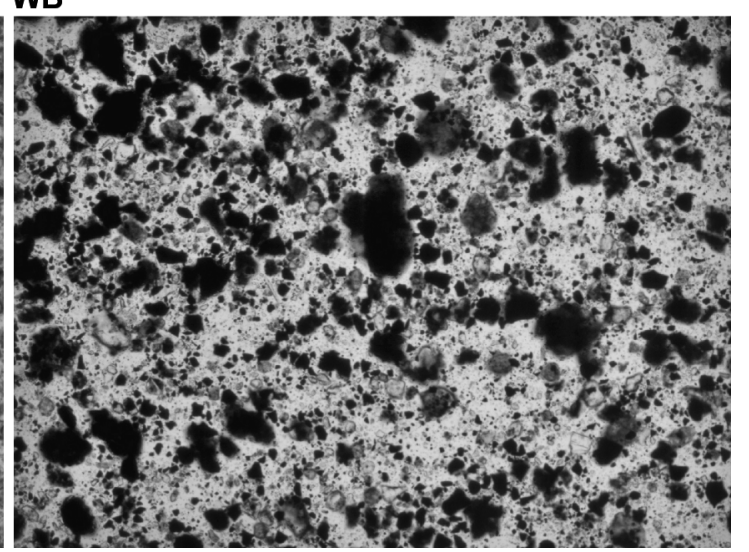

Fig. 1. Capping materials used in the experiment (magnification 100 $\times$ ): (TS) natural test sediments and (WB) water-based drill cuttings. Note the difference in grey shading between the 2 materials (Micrographs: Wenche Eikrem, NIVA)

preted as oxidation and precipitation of upwards diffusing $\mathrm{Fe}^{2+}$ and $\mathrm{Mn}^{2+}$ ions, indicative of increased sediment oxygen consumption. Neither black spots on the sediment surface nor the characteristic malodor of $\mathrm{H}_{2} \mathrm{~S}$ were observed in any boxes.

\section{Particle properties}

The CO sediment was classified as 'fine sand', with a pelite $(<0.063 \mathrm{~mm})$ content of $39 \%$ (Table 1$)$. The FI sediment and both capping materials (TS and WB) contained 57 to $88 \%$ pelite and were classified as 'silt'. Notably, WB had the highest gravel content $(1.9 \%)$. Additionally, it was the only sediment that was negatively skewed (i.e. with the tail towards the coarser fraction), and it had the highest kurtosis value (i.e. the grain size distribution curve was most highly peaked). All particles had a convex and relatively round shape, and no major differences were observed between the analyzed sediments FI, CO,
TS and WB (Table 1). In the microscope images (Fig. 1), the drill cuttings were much darker than the natural sediments because of the black ilmenite, but there was no obvious difference in shape.

\section{Benthic fauna}

In total, 166 taxa and 11703 individuals were counted in the mesocosm boxes. Per treatment, the mean number of taxa ranged from 39 to 70 , the mean abundance from 280 to 844, mean total biomass ranged from 9.6 to $57.4 \mathrm{~g}$ and, excluding echinoids, from 7.1 to $20.9 \mathrm{~g}$ (Fig. 2). Echinoids were patchily distributed between the boxes, and biomass calculations were therefore conducted with and without this group. Nemertini, Nematoda, the annelids Prionospio cirrifera, Spiophanes kroyeri, Chaetozone setosa, Cirrophorus cf. lyra and Exogone sp. and the bivalve Thyasira equalis were the most abundant taxa (Table 2). 
Table 2. Average abundance per treatment of the 15 most abundant taxa at Day 48 (end of expt). Coarse (CO) and fine (FI) box core sediment samples $\left(0.09 \mathrm{~m}^{2}\right)$ were treated by addition (OM) or no addition (NO) of organic matter, and by addition of 2 different capping materials $(\mathrm{TS}=$ test sediment, $\mathrm{WB}=$ water-based drill cuttings $) . \mathrm{A}=$ Annelida; $\mathrm{M}=\mathrm{Mollusca}$; indet. $=$ undetermined

\begin{tabular}{|c|c|c|c|c|c|c|c|c|}
\hline \multirow{3}{*}{ Taxon } & \multicolumn{4}{|c|}{$\mathrm{CO}$} & \multicolumn{4}{|c|}{$\mathrm{FI}$} \\
\hline & \multicolumn{2}{|c|}{$-\mathrm{OM}-$} & \multicolumn{2}{|c|}{$-\mathrm{NO}-$} & \multicolumn{2}{|c|}{$-\mathrm{OM}-$} & \multicolumn{2}{|c|}{$-\mathrm{NO}$} \\
\hline & $\mathrm{TS}$ & WB & TS & WB & $\mathrm{TS}$ & WB & TS & WB \\
\hline Nemertinea indet. & 46.0 & 37.0 & 43.3 & 31.3 & 69.0 & 81.0 & 66.0 & 64.0 \\
\hline Nematoda indet. & 52.0 & 46.3 & 65.0 & 51.3 & 64.3 & 35.3 & 20.3 & 23.0 \\
\hline Exogone sp. (A) & 17.7 & 9.3 & 14.0 & 5.3 & 31.3 & 34.0 & 22.7 & 13.7 \\
\hline Cirrophorus cf. lyra (A) & 24.7 & 12.0 & 14.3 & 11.7 & 28.3 & 21.7 & 23.0 & 21.3 \\
\hline Prionospio cirrifera (A) & 35.0 & 8.7 & 11.0 & 1.3 & 161.7 & 38.0 & 26.7 & 3.0 \\
\hline Spiophanes kroeyeri (A) & 51.7 & 19.7 & 45.3 & 8.7 & 76.7 & 36.0 & 13.3 & 9.7 \\
\hline Caulleriella sp. (A) & 21.7 & 3.3 & 8.0 & 1.3 & 25.0 & 9.0 & 14.7 & 3.0 \\
\hline Chaetozone setosa (A) & 26.7 & 14.3 & 9.7 & 1.7 & 90.7 & 37.0 & 22.7 & 4.3 \\
\hline Heteromastus filiformis (A) & 19.0 & 26.0 & 52.0 & 35.0 & 38.0 & 40.3 & 77.0 & 138 \\
\hline Euclymeninae indet. (A) & 8.7 & 4.7 & 15.3 & 7.3 & 28.3 & 22.3 & 4.7 & 7.0 \\
\hline Oligochaeta indet. (A) & 32.7 & 23.0 & 6.7 & 5.0 & 4.3 & 12.7 & 10.7 & 7.0 \\
\hline Thyasira equalis (M) & 25.7 & 13.0 & 26.3 & 15.0 & 51.7 & 26.3 & 50.7 & 20.7 \\
\hline Thyasira pygmaea (M) & 9.0 & 3.3 & 12.0 & 2.3 & 18.3 & 9.0 & 18.3 & 2.3 \\
\hline Abra nitida (M) & 27.3 & 1.0 & 8.7 & 1.7 & 16.3 & 2.7 & 7.7 & 1.3 \\
\hline Onchnesoma steenstrupi (M) & 12.3 & 10.0 & 15.0 & 11.0 & 3.3 & 1.0 & 1.3 & 1.7 \\
\hline
\end{tabular}
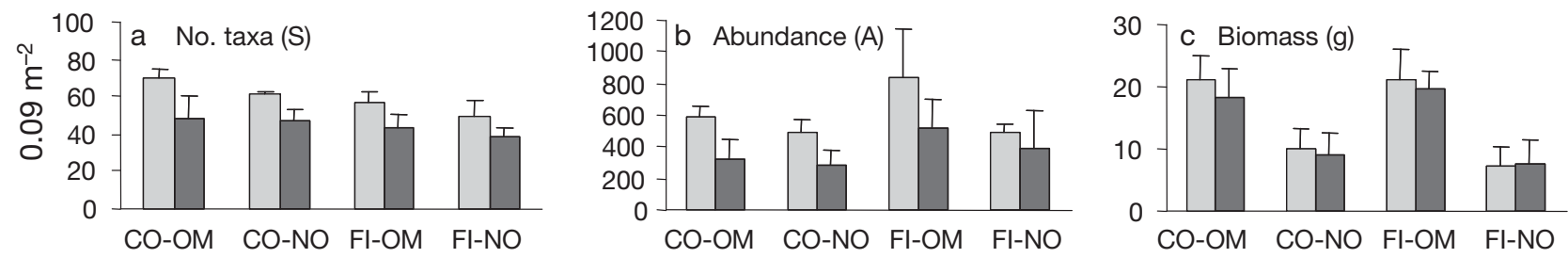

Fig. 2. Number of (a) taxa (S), (b) abundance (A) and (c) biomass (without echinoids), measured at Day 48 (end of expt), in response to the addition of test sediment (TS, light bars) and water-based drill cuttings (WB, dark bars) in combination with other experimental variables. $\mathrm{FI}=$ fine sediment community, $\mathrm{CO}=$ coarse sediment community, $\mathrm{OM}=$ organic matter, $\mathrm{NO}=$ no organic matter. Means per treatment $\left(0.09 \mathrm{~m}^{2}\right)+\mathrm{SD}$

PERMANOVA and 3-factor ANOVA on univariate parameters (Table 3 ) showed that all 3 experimental factors were significant for the faunal composition. The WB boxes had fewer taxa and lower abundance than the TS boxes, and the NO boxes had lower abundance and biomass than the OM boxes (Fig. 2). In addition, number of taxa was significantly higher in the CO than in the FI boxes. No significant interactions between factors were observed in the macrofauna community responses.

In the MDS plot (Fig. 3) there was a clear separation according to community, where the $\mathrm{CO}$ boxes were placed in the upper left of the plot and the FI boxes in the lower right. There was also some separation reflecting the capping material with WB boxes to the lower left and TS boxes to the upper right. The factor organic matter seemed less important, although some separation was visible. Notably, the WB boxes were more scattered than the TS boxes in the plot. The stress value of the ordination was relatively high (0.13), but as the ordination showed good agreement with the PERMANOVA results (Table 3), the plot is considered to adequately represent the community composition.

\section{Benthic oxygen flux}

The oxygen fluxes were directed into the sediments, i.e. oxygen was consumed. Prior to any additions, the average total oxygen flux $\left(J_{\text {tot }} 2\right)$ ranged from 6.4 to $9.8 \mathrm{mmol} \mathrm{m}^{-2} \mathrm{~d}^{-1}$ (Fig. 4a), and was significantly higher in the warmer OM $\left(9.5^{\circ} \mathrm{C}\right)$ water bath $\left(9.4 \pm 1.0 \mathrm{mmol} \mathrm{m}^{-2} \mathrm{~d}^{-1}\right)$ than in the cooler $\mathrm{NO}\left(7.3^{\circ} \mathrm{C}\right)$ water bath $\left(7.3 \pm 1.5 \mathrm{mmol} \mathrm{m}{ }^{-2} \mathrm{~d}^{-1}\right)(2$-factor ANOVA, $F=16.64, \mathrm{p}<0.001) . J_{\text {tot } \mathrm{O} 2}$ was initially not signifi- 
Table 3. Three-factor PERMANOVA for faunal composition and 3-factor ANOVA (Community, Organic matter and Capping material; see text for details) for number of taxa (S), abundance (A) and biomass (excluding echinoids), measured at Day 48 (end of expt). $F_{\text {crit } 0.05}=4.49$ for 3-factor ANOVA using the residual MS as denominator. Significant levels in PERMANOVA were obtained from $p$-values calculated by permutations of residuals under a reduced model. ${ }^{*} \mathrm{p}<0.05$, ${ }^{* *} \mathrm{p}<0.01$, ${ }^{* * *} \mathrm{p}<0.001$

\begin{tabular}{|c|c|c|c|c|c|c|c|c|c|}
\hline \multirow[t]{2}{*}{ Factors } & \multirow[t]{2}{*}{ df } & \multicolumn{2}{|c|}{ PERMANOVA } & & & \multicolumn{2}{|c|}{$-\mathrm{ANOVA}-$} & \multicolumn{2}{|c|}{ Biomasc } \\
\hline & & MS & Pseudo- $F$ & MS & $F$ & MS & $F$ & MS & $\mathrm{F}$ \\
\hline Community & 1 & 2852 & $5.86^{* * *}$ & 0.037 & $10.49^{* *}$ & 0.075 & 3.63 & 2.90 & 0.178 \\
\hline Organic matter & 1 & 2117 & $4.35^{* * *}$ & 0.010 & 2.78 & 0.105 & $5.02^{*}$ & 835 & $51.3^{* * *}$ \\
\hline Capping material & 1 & 2483 & $5.10^{* * *}$ & 0.093 & $26.46^{* * *}$ & 0.301 & $14.47^{* *}$ & 10.2 & 0.625 \\
\hline Organic matter × Community & 1 & 696 & 1.43 & 0.000 & 0.046 & 0.022 & 1.07 & 7.80 & 0.478 \\
\hline Capping material $\times$ Community & 1 & 509 & 1.05 & 0.001 & 0.335 & 0.009 & 0.415 & 7.80 & 0.478 \\
\hline Capping material $\times$ Organic matter & 1 & 485 & 0.997 & 0.002 & 0.450 & 0.003 & 0.159 & 3.35 & 0.205 \\
\hline $\begin{array}{l}\text { Capping material } \times \text { Community } \times \\
\text { Organic matter }\end{array}$ & 1 & 289 & 0.594 & 0.001 & 0.147 & 0.000 & 0.017 & 0.673 & 0.041 \\
\hline Residual & 16 & 487 & & 0.004 & & 0.021 & & 16.3 & \\
\hline
\end{tabular}

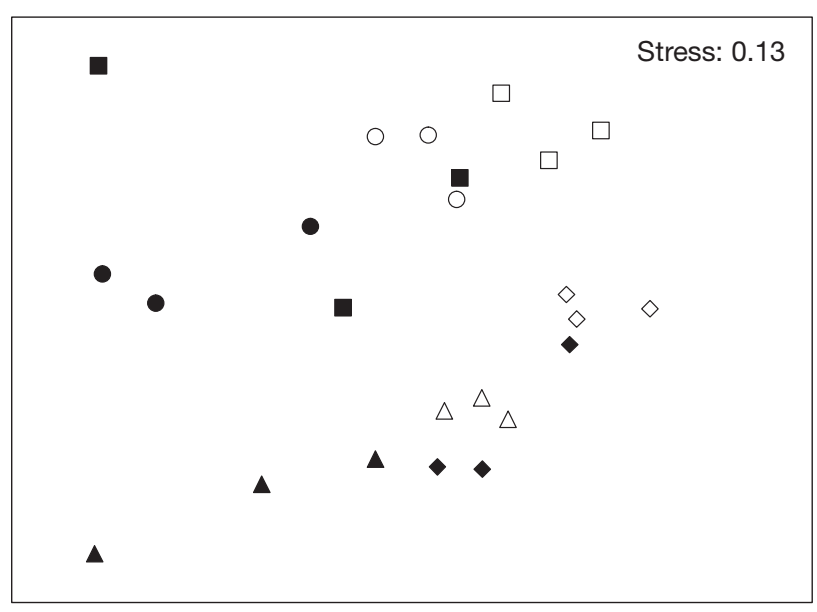

Fig. 3. Non-metrical multidimensional scaling (MDS) of faunal replicates measured at Day 48 (end of expt) in box core sediment samples subject to 8 different treatments: $\Delta=$ FINO-TS, $\boldsymbol{\Delta}=$ FI-NO-WB, O = CO-NO-TS, $\bullet=$ CO-NO-WB, $\diamond=$ FI-OM-TS, $\bullet=$ FI-OM-WB, $\square=\mathrm{CO}-\mathrm{OM}-\mathrm{TS}, \boldsymbol{\square}=\mathrm{CO}-$ $\mathrm{OM}-\mathrm{WB}$ (where $\mathrm{FI}=$ fine sediment community, $\mathrm{CO}=$ coarse sediment community, $\mathrm{OM}=$ organic matter, $\mathrm{NO}=$ no organic matter, WB = water-based drill cuttings, TS = test sediment)

cantly different between the $\mathrm{CO}$ and FI communities (2-factor ANOVA, $F=0.71, \mathrm{p}=0.41$ ). After addition of drill cuttings on Day 1 and organic matter on Day 7: oxygen consumption increased sharply in the WB and OM treatments, but not in the TS and NO treatments. Although these highly amplified fluxes lasted for a few days only, the effects of capping material and organic matter were maintained throughout the experiment, as evidenced by statistically significant results for Days 21 and 47 (Table 4, Fig. 4a) (Day 47; 3-factor ANOVA, $F=13.99, p=$
0.0018 for capping material and $F=16.50, \mathrm{p}=0.0009$ for organic matter).

The average diffusive flux of oxygen $\left(J_{\text {diff }}\right.$ O2 $)$ on Day 21 ranged from 2.5 to $8.1 \mathrm{mmol} \mathrm{m}^{-2} \mathrm{~d}^{-1}$ (Fig. 5a), and was generally lower than $J_{\text {tot O2 }}$ (Fig. 4a). Again, the effects of capping and organic matter were statistically significant, with WB $>$ TS for $J_{\text {diff O2 }}$ and TS > WB for $J_{\text {tot O2 }}: J_{\text {diff O2 }}($ Table 4$)$. The average $J_{\text {tot O2 }}: J_{\text {diff }}$ O2 ratio ranged from 1.4 to 4.0 , with significant 2- and 3-way interactions (Table 4, Fig. 5b). Nevertheless, the effect of capping material was very clear, with higher $J_{\text {tot O2 }}: J_{\text {diff O2 }}$ in TS compared to WB boxes.

Average oxygen concentration in the sediment pore water on Day 21 ranged from 0.14 to $0.64 \mathrm{mmol}$ $\mathrm{m}^{-2}$ (Fig. 5c). Both addition of drill cuttings and organic matter significantly reduced oxygen concentration deeper in the sediment pore water (Table 4).

\section{Benthic nutrient fluxes}

As with oxygen, nitrate was consumed in the sediments. On Day 0 , the average nitrate flux ranged from 0.05 to $0.14 \mathrm{mmol} \mathrm{m}^{-2}$ day $^{-1}$ (Fig. 4b), with significantly higher flux in the OM $\left(9.5^{\circ} \mathrm{C}\right)$ water bath $\left(0.13 \pm 0.033 \mathrm{mmol} \mathrm{m}^{-2} \mathrm{~d}^{-1}\right)$ than in the NO $\left(7.3^{\circ} \mathrm{C}\right)$ water bath $\left(0.06 \pm 0.03 \mathrm{mmol} \mathrm{m} \mathrm{m}^{-2} \mathrm{~d}^{-1}\right)$ (2-factor ANOVA $; F=22.88, \mathrm{p}<0.001)$. No significant difference between $\mathrm{CO}$ and FI communities was observed $(F=0.40 ; \mathrm{p}=0.54)$. Additions of drill cuttings and organic matter were followed by a rapid increase in nitrate uptakes. The increased nitrate uptake in the WB boxes was maintained throughout the experiment, evidenced by a significant effect of capping 
Table 4. Three-factor ANOVA for total flux of $\mathrm{O}_{2}\left(J_{\text {tot O}}\right), \mathrm{NO}_{3}{ }^{-}$and $\mathrm{NH}_{4}{ }^{+}$, diffusive $\mathrm{O}_{2}$ flux $\left(J_{\text {diff } \mathrm{O}_{2}}\right)$, and pore water $\mathrm{O}_{2}$ (dissolved oxygen concentration in sediment pore water), measured on Day 21 of the experiment. $F_{\text {crit }} 0.05=4.49$ for 3 -factor ANOVA on $J_{\text {tot } \mathrm{O} 2}, \mathrm{NO}_{3}{ }^{-}$and $\mathrm{NH}_{4}{ }^{+}$and $F_{\text {crit } 0.05}=4.6$ for 3 -factor ANOVA on $J_{\text {diff } \mathrm{O} 2}, J_{\text {tot O2 }}: J_{\text {diff } \mathrm{O} 2}$ and porewater $\mathrm{O}_{2}$, using the residual MS as denominator. ${ }^{*} \mathrm{p}<0.05,{ }^{* *} \mathrm{p}<0.01,{ }^{* * *} \mathrm{p}<0.001$

\begin{tabular}{|c|c|c|c|c|c|c|c|c|c|c|c|c|c|c|}
\hline \multirow[t]{2}{*}{ Factors } & \multirow[t]{2}{*}{$\mathrm{df}$} & \multicolumn{2}{|c|}{$-J_{\mathrm{tot} \mathrm{O} 2}-$} & \multicolumn{2}{|c|}{$-\mathrm{NO}_{3}{ }^{-}-$} & \multicolumn{2}{|c|}{$-\mathrm{NH}_{4}{ }^{+}-$} & \multicolumn{3}{|c|}{$\mathrm{df}-J_{\text {diff } \mathrm{O} 2}-$} & \multicolumn{2}{|c|}{$J_{\text {tot } \mathrm{O} 2}: J_{\text {diff } \mathrm{O} 2}$} & \multicolumn{2}{|c|}{ Pore water $\mathrm{O}_{2}$} \\
\hline & & MS & $F$ & MS & $F$ & MS & $F$ & & MS & $F$ & MS & $F$ & MS & $F$ \\
\hline Community & 1 & 0.794 & 0.434 & 0.001 & 0.959 & 0.006 & 2.90 & 1 & 0.007 & 0.627 & 0.017 & 2.05 & 0.014 & 1.67 \\
\hline Organic matter & 1 & 93.5 & $51.0^{* * *}$ & 0.009 & $6.24^{*}$ & 0.021 & $9.23^{* *}$ & 1 & 0.356 & $31.6^{* * *}$ & 0.016 & 1.95 & 0.227 & $26.7^{* * *}$ \\
\hline Capping material & 1 & 12.8 & $6.10^{*}$ & 0.024 & $17.0^{* * *}$ & 0.058 & $25.9^{* * *}$ & 1 & 0.272 & $24.2^{* * *}$ & 0.115 & $13.8^{* *}$ & 0.266 & $31.2^{* * *}$ \\
\hline Organic matter $\times$ Community & 1 & 1.24 & 0.677 & 0.000 & 0.106 & 0.000 & 0.209 & 1 & 0.002 & 1.81 & 0.044 & $5.34^{*}$ & 0.000 & 0.005 \\
\hline Capping material $\times$ Community & 1 & 0.091 & 0.049 & 0.002 & 1.18 & 0.002 & 1.04 & 1 & 0.048 & 4.23 & 0.029 & 3.50 & 0.034 & 3.97 \\
\hline $\begin{array}{l}\text { Capping material } \times \text { Organic } \\
\text { matter }\end{array}$ & 1 & 1.42 & 0.774 & 0.002 & 1.18 & 0.000 & 0.053 & 1 & 0.031 & 2.76 & 0.084 & $10.10^{* *}$ & 0.020 & 2.32 \\
\hline $\begin{array}{l}\text { Capping material } \times \text { Community } \\
\times \text { Organic matter }\end{array}$ & 1 & 1.51 & 0.824 & 0.001 & 0.755 & 0.000 & 0.163 & 1 & 0.022 & 1.99 & 0.044 & $5.34^{*}$ & 0.000 & 0.000 \\
\hline Residual & 16 & 1.83 & & 0.001 & & 0.002 & & & 0.001 & & 0.002 & & 0.009 & \\
\hline
\end{tabular}

a

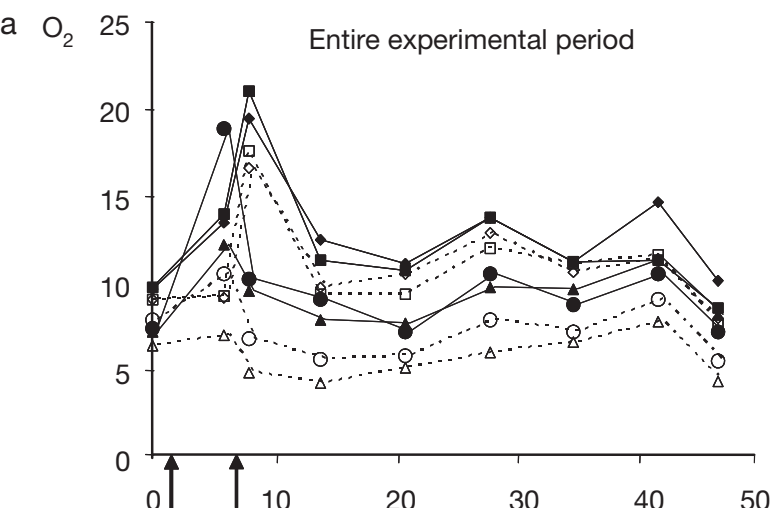

b $\mathrm{NO}_{3}^{-}$

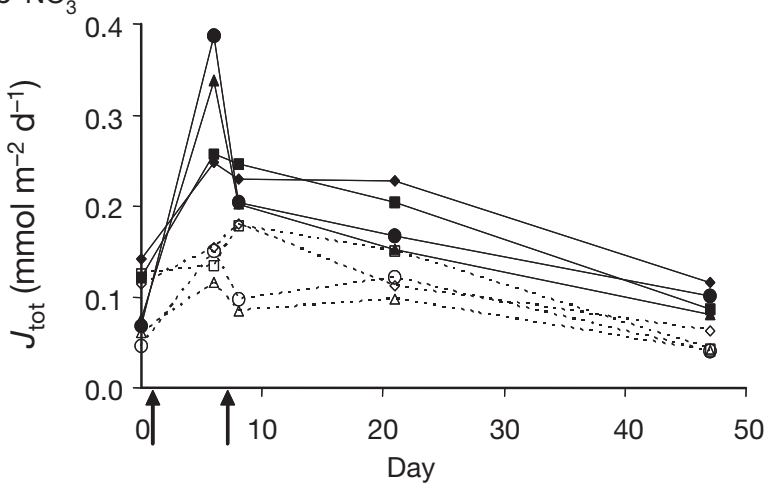

C $\mathrm{NH}_{4}^{+}$

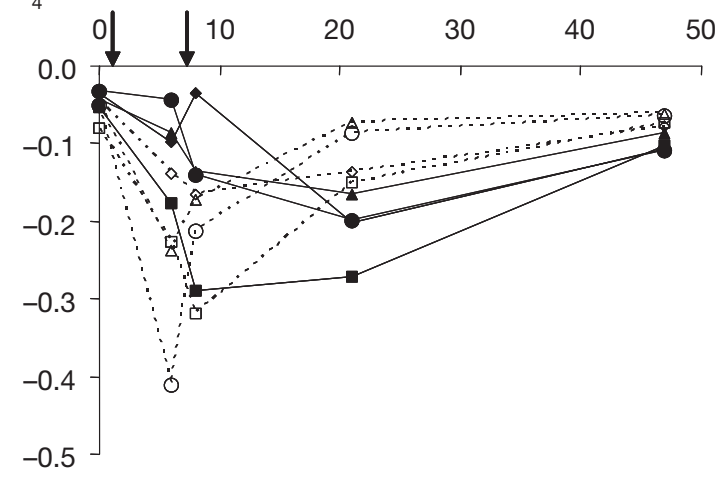

Day 21
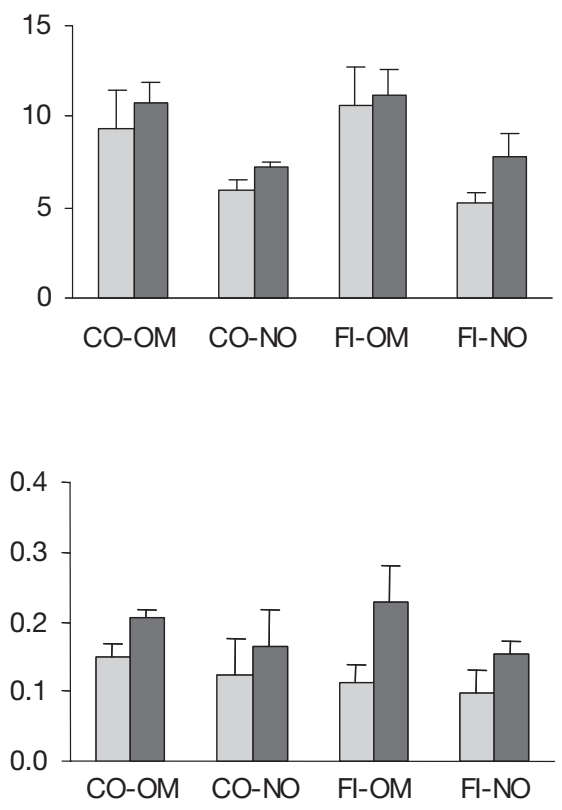

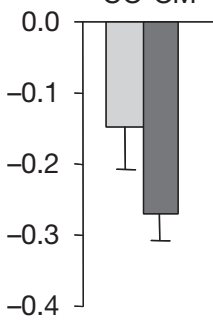

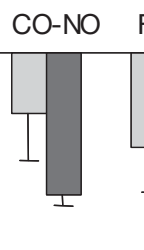

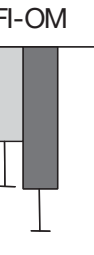

$\mathrm{Fl}-\mathrm{NO}$

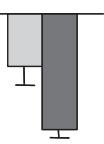



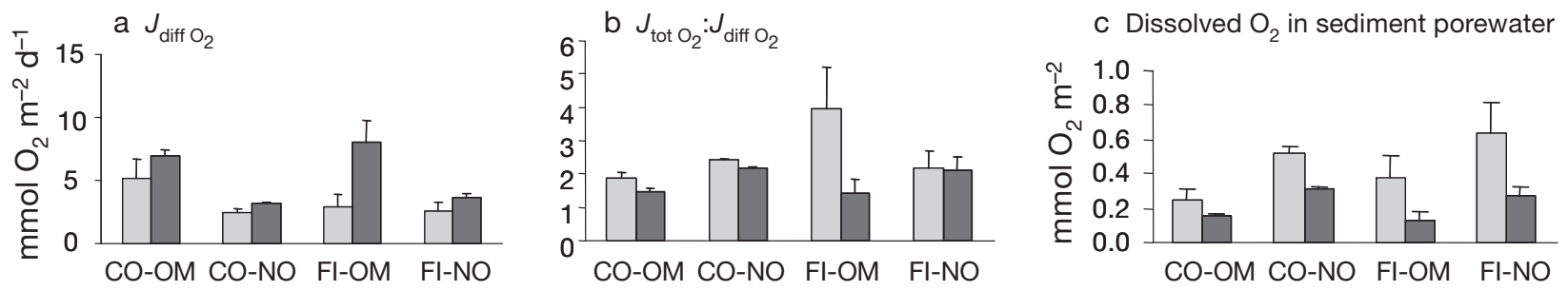

Fig. 5. Average (+SD) values on Day 21 for (a) diffusive flux of oxygen $J_{\text {diff O2, }}$ (b) ratio between total and diffusive flux of oxygen $J_{\text {tot O2 }}: J_{\text {diff } \mathrm{O}_{2}}$ and (c) dissolved oxygen in sediment pore water, in response to the addition of TS (light bars) and WB (dark bars) in combination with other experimental variables. Abbreviations as in Fig. 2

material on Day 21 (Table 4) and Day 47 (3-factor ANOVA $\left._{i} F=6.59, \mathrm{p}<0.001\right)$. The increased uptake in the boxes with organic matter (OM) was significant on Day 21 (Table 4), but not on Day 47 (3-factor ANOVA $_{i} F=1.88, \mathrm{p}=0.190$ ).

All sediments released ammonium to the overlying water. On Day 0, the average ammonium flux ranged from -0.03 to $-0.08 \mathrm{mmol} \mathrm{m}^{-2} \mathrm{~d}^{-1}$ (Fig. $4 \mathrm{c}$ ), and there was no significant difference between water baths or communities (2-factor ANOVA $; F=0.98, \mathrm{p}=0.33$ for both factors). Addition of WB and TS was accompanied by increased ammonium release. Initially, the response was higher in TS than in WB, but after Day 8 the release was larger in the WB than TS boxes. This was confirmed by the statistical analyses on Day 21 (Table 4) and Day 47 (3-factor ANOVA; $F=$ $1.39, \mathrm{p}=0.012$ ). The initial response of organic matter was variable, but on Day 21 the ammonium release from the sediment was significantly higher in the OM compared to the NO boxes (Table 4, Fig. 4c).

\section{DISCUSSION}

In the present study, we found that the biological and biogeochemical responses of drill cuttings and organic matter were similar in 2 inherently different communities. Moreover, we found that the biogeochemical response to the addition of drill cuttings resembled the response to the addition of organic matter, which points to an organic phase in the water-based drill cuttings. On the other hand, whereas addition of organic matter had a positive effect on macrofaunal abundance and biomass, addi- tion of drill cuttings caused faunal depletion. The drill cuttings layer of $6.5 \mathrm{~mm}$ is considered representative for sediments surrounding offshore wells drilled with water-based drilling muds, where a $1 \mathrm{~cm}$ layer of cuttings is typical as far out as $250 \mathrm{~m}$ from the well (Rye \& Furuholt 2010).

The present experiment was carried out with benthic communities from a fjord system, rather than with continental shelf communities where the drilling operations take place. These systems will of course be different with respect to both top-down and bottom-up factors, but at the same time, the continental shelf communities that are subject to drilling activities are themselves highly variable. For instance, in the Norwegian Sector alone, oil and gas exploration is carried out at locations between $56^{\circ}$ and $71^{\circ} \mathrm{N}$ and at depths ranging from 60 to $450 \mathrm{~m}$. As all the most dominant taxa in the present experiment (Table 2) are abundant in offshore drilling locations in the Norwegian Sector (Norwegian Oil Industry Database), the observed effects in the present experiments are considered relevant for areas impacted by petroleum activities.

\section{Effects of the inherent factor community}

Although the $\mathrm{CO}$ and FI communities shared most of the species found (Table 2), the PERMANOVA (Table 3) and the MDS ordination (Fig. 3) clearly showed that the 2 communities were different. The number of taxa was significantly higher in the coarse than in the fine sediment, which agrees well with a general pattern explained by the fact that coarser

Fig. 4. Average total flux $J_{\text {tot }}$ per treatment for (a) oxygen $\left(\mathrm{O}_{2}\right)$, (b) nitrate $\left(\mathrm{NO}_{3}{ }^{-}\right)$and (c) ammonium $\left(\mathrm{NH}_{4}{ }^{+}\right)$throughout the experimental period (left) and on Day $21(+\mathrm{SD})$ (right) in box core sediment samples subject to 8 different treatments: $\Delta=$ FINO-TS, $\boldsymbol{\Delta}=$ FI-NO-WB, O = CO-NO-TS, $\bullet=$ CO-NO-WB, $\diamond=$ FI-OM-TS, $\bullet=$ FI-OM-WB, $\square=$ CO-OM-TS, $\boldsymbol{\square}=$ CO-OM-WB (abbreviations as in Fig. 3). Arrows in the left panels denote addition of capping material (Day 1) and of organic matter in OM boxes (Day 7). Positive fluxes are directed into the sediment and negative fluxes are directed out of the sediment. Light bars $=$ test sediment (TS), dark bars = water-based drill cuttings (WB) 
sediments are more heterogeneous than fine, which provides more niches and potentially higher biodiversity (e.g. Etter \& Grassle 1992, Gray 2002). Interestingly, despite of a different community composition, no differences were observed in the biogeochemical response variables. Thus, in the present experiment, the measured ecosystem function did not depend on the taxa richness or vary between 2 different communities. Rather than species richness as such, species-specific traits are often more important for ecosystem functions (e.g. Lohrer et al. 2004, Mermillod-Blondin et al. 2005, Norling et al. 2007, Braeckman et al. 2010). Ecosystem engineers, like Brissopsis lyrifera, were patchily distributed between boxes, but did not vary systematically between the communities, which may explain why the 2 otherwise structurally different communities showed similar ecosystem functions.

\section{Effects of the experimental factors organic matter and capping material}

\section{Biological effects}

In NO boxes, abundance and biomass were significantly lower than in OM boxes, and both the PERMANOVA and the MDS showed significant effects of the factor organic matter on macrofaunal composition (Table 3, Fig. 3). Since the relative difference between the $\mathrm{OM}$ and NO boxes was larger for biomass than abundance, and since there was no or only marginal recruitment in the mesocosm, the reduction of organisms in the NO boxes is interpreted as starvation.

In the present study, $6.5 \mathrm{~mm}$ layers of drill cuttings significantly reduced abundance and number of taxa compared to natural sediment addition, and both the PERMANOVA and the MDS ordination confirmed that the factor capping material was important for faunal composition (Table 3, Fig. 3). The lack of interaction with the 2 other experimental factors showed that the response of drill cuttings occurred independently of organic matter addition and community in the present study. However, the relation between disturbances and broader-scale changes in community is highly complex (Thrush et al. 2008), and it is too early to conclude that the responses to drill cuttings do not vary between communities or between different organic matter and temperature regimes.

The annelids Prionospio cirrifera, Caulleriella sp. and Chaetozone setosa and the bivalves Thyasira equalis, Thyasira pygmaea and Abra nitida had lower abundance in the boxes with drill cuttings than the boxes with natural test sediment (Table 2). Of these, both $P$. cirrifera and $A$. nitida have been recorded as sensitive to drill cuttings in earlier studies (Schaanning et al. 1996, 2008, Terlizzi et al. 2005, Trannum et al. 2010). In contrast, C. setosa has been considered tolerant to drill cuttings discharges, and was suggested as an indicator species in a biological index to assess disturbance due to drilling activities (Ugland et al. 2008). The response of $C$. setosa was therefore not expected.

\section{Biogeochemical effects}

Whereas the biological effects of organic matter and drill cuttings were different from each other, notably the biogeochemical responses to these 2 additions were almost identical. Sediment consumption of oxygen and nitrate and sediment release of ammonium increased, and the amount of dissolved oxygen in the sediment pore water decreased significantly in WB boxes compared to TS boxes and in OM boxes compared to NO boxes (Table 4, Figs. 4 $\& 5$ ). This response is interpreted as degradation of organic compounds utilizing oxygen and subsequently nitrate. Such organic compounds were obviously present in the added organic matter; but they were also present in the drill cuttings, most likely because the drilling mud contained polyalkylene glycol. Notably, in the WB boxes there was a delayed response from the sharp peaks of oxygen and nitrate uptake 5 to $10 \mathrm{~d}$ after cuttings addition to the much broader peaks of ammonium with maxima frequently occurring $20 \mathrm{~d}$ after addition (Fig. 4). Therefore, a plausible explanation of the sequence of events is an initial phase with rapid bacterial degradation of the organic compounds in the cuttings, followed by a second phase with faunal mortality and accompanying release of ammonium from decaying organisms.

$J_{\text {tot O2 }}: J_{\text {diff O2 }}$ ranged from 1.0 to 4.8 , which indicates significant impacts of faunal processes in some boxes. This ratio corresponds with the ratio of 1.1 to 4.8 recorded by Hulth et al. (1994) for Arctic sediments, and also with ratios of 1.4 for Danish coastal sediments (Rasmussen \& Jørgensen 1992) and of 3 to 4 for continental shelf sediments (Archer \& Devol 1992). $J_{\text {tot O2 }}: J_{\text {diff O2 }}$ was clearly lower in the WB than in the TS boxes (Table 4, Fig. 5b), which indicates a higher contribution of diffusion-mediated $\mathrm{O}_{2}$ consumption to the total uptake of oxygen. Again, biodegradation of organic compounds or dead organisms emerges as the driving factor for the oxygen conditions in the WB boxes. Interestingly, for $J_{\text {tot O2 }}$ : 
$J_{\text {diff O2 }}$ significant interaction effects between organic matter and the 2 other factors were observed, including a 3-way interaction for $J_{\text {tot O2 }}: J_{\text {diff O2}}$. Thus, bioturbating organisms showed a very complex behavioural response to organic matter in combination with the 2 other experimental factors.

Prior to any additions, the biogeochemical fluxes showed that the temperature difference per se produced significantly higher uptake rates of oxygen and nitrate in the 'ambient' temperature (OM) than in the 'reduced' temperature (NO) treatments. The cooling of the NO boxes probably lowered faunal and microbial metabolism and chemical rates in the sediments. Fluxes of oxygen and nutrients are recognized as valid indicators of ecosystem functioning (e.g. Lohrer et al. 2004, 2010, Norling et al. 2007), and the temperature difference which provided this difference in function was $2^{\circ} \mathrm{C}$. Notably, according to the 2009 Copenhagen Accord (unfccc.int/resource/ docs/2009/cop15/eng/107.pdf), the increase in global temperature due to climate change should be within $2^{\circ} \mathrm{C}$, a level which corresponds with the temperature difference in the present experiment.

Another interesting finding was that all fluxes increased after addition of capping material, independently of whether TS or WB was added. Increased fluxes of phosphate, silicate and nitrate have been observed in previous experiments after addition of thin (3-6 $\mathrm{mm}$ ) cap layers (Schaanning et al. 2008, Trannum et al. 2010), and it appears that this is a common response of benthic communities to addition of a thin cap layer. The capping itself probably forced the organisms to rebuild tubes and burrows, move to their original sediment position and increase bioirrigation, which are mechanisms that increase solute exchange across the sediment-water interface (Nizzoli et al. 2007 and references herein).

\section{Impact mechanisms of drill cuttings}

Possible explanations for the observed biological effects of drill cuttings are evaluated below:

Burial. Burial per se was similar in all experimental boxes, where either $6.5 \mathrm{~mm}$ natural test sediments or water-based drill cutting were added. In a previous mesocosm-experiment, layers up to $24 \mathrm{~mm}$ of natural test sediment did not affect benthic communities whereas faunal effects of drill cuttings were found from $\sim 6 \mathrm{~mm}$ (Trannum et al. 2010). Lack of faunal effects of sedimentation by natural particles has also been observed in previous studies (e.g. Jackson \& James 1979, Maurer et al. 1982, Bellchambers \&
Richardson 1995, Smith \& Rule 2001). Thus, the burial component of faunal effects of water-based drill cuttings should in our view be scaled down, while other impact factors should be investigated further.

Grain size change. Although there was a minor difference in the particle size distribution curves between the natural sediment and drill cuttings, both capping materials were characterized as silt, and the composition is considered relatively similar (Table 1). Thus, grain size effects were most probably not the most important impact factor in the present experiment.

Particle shape. Drill cuttings have frequently been assumed to have an angular configuration (Fertl et al. 2002), which has been put in context with damage of ciliary structures, gill membranes and digestive gland cells of mussels (Cranford et al. 1999, Barlow \& Kingston 2001, Bechmann et al. 2006). However, the efforts undertaken in the present study did not reveal any difference in the particle shape between drill cuttings and natural sediments (Table 1, Fig. 1), and particle sharpness is not considered to be important in the present experiment.

Oxygen effects. In the present study, oxygen levels were lowest in the sediments treated with both WB and OM, as expected (Figs. 4a \& 5). The oxygen penetration depth at Day 21 ranged from $1.5 \mathrm{~mm}$ (in a FIOM-WB box, corresponding to a dissolved $\mathrm{O}_{2}$-concentration in sediment pore water of $0.12 \mathrm{mmol} \mathrm{m}^{-2}$ ) to $11.8 \mathrm{~mm}$ (in a FI-NO-TS box, corresponding to a dissolved $\mathrm{O}_{2}$-concentration of $0.85 \mathrm{mmol} \mathrm{m}^{-2}$ ). Although the oxygen penetration depth was small in some boxes, there was no tendency of most severe faunal effects in boxes having the lowest oxygen penetration depth (WB-OM boxes) (Figs. $2 \& 3$ ). In a previous mesocosm experiment with layer thicknesses up to $24 \mathrm{~mm}$, oxygen depletion was concluded to severely affect the benthic fauna (Trannum et al. 2010), but at the present layer thickness of $6.5 \mathrm{~mm}$, oxygen depletion is not considered to have been the only impact factor.

Toxic effects. Generally, water-based muds have been considered low- or non-toxic (Neff 2005 and references herein), and toxic effects were not expected. However, as none of the impact factors presented above seemed to sufficiently explain the observed faunal mortality, toxicity remains a hypothesis. In both mesocosm experiments and field investigations, it is difficult to distinguish toxic effects from other impact factors. Therefore, standardized bioassay toxicity tests were performed using the algae Skeletonema costatum, the copepod Tisbe battagliai and oyster embryos. Acute toxic effects were found 
for water-based drill cuttings pore water on the copepod T. battagliai and water-based drill cutting organic extracts on both the algae $S$. costatum and oyster embryos (K. Norling et al. unpubl.). Although acute toxic effects cannot be directly transferred to the macrofaunal community level, this finding reveals a toxic potential of water-based drill cuttings not previously described. Thus, there is a clear need to investigate toxic effects of water-based drill cuttings in more detail. Such testing should be performed on bulk drill cuttings, rather than the single mud components, which hitherto has been the requirement for toxicity testing in North Sea countries.

The present study has shown that the particular effect mechanisms of water-based drill cuttings may be more complex than previously assumed. Although the study did not reveal any relation between waterbased drill cuttings and organic matter or community, it is still too early to establish any generic relationship between water-based drill cuttings and benthic responses. It is important that the precautionary principle is the basis of the regulation of discharges of water-based drill cuttings in future discharges from oil and gas exploration.

Acknowledgements. We are grateful to the crew on RV 'Trygve Braarud' and the staff at Marine Research Station at Solbergstrand for their highly skilled assistance during field sampling and experimental performance. We also thank StatoilHydro for providing the drill cuttings. The deceased Professor Frode Olsgard is warmly thanked for project ideas and practical work during the experiment as well as discussions concerning impact factors of drill cuttings. JoLynn Carroll, Ketil Hylland, Henrik Rye and 2 anonymous referees are thanked for useful comments on the manuscript. The study was funded by the Norwegian Research Council (Projects $17333 /$ S40 and 164410/S40, the latter a doctoral grant to H.C.T), which is gratefully acknowledged.

\section{LITERATURE CITED}

Aller RC (1982) The effects of macrobenthos on chemical properties of marine sediment and overlying water. In: McCall PL, Tevesz MJS (eds) Animal-sediment relations-the biogenic alteration of sediments. Topics in geobiology, Vol 2. Plenum Press, New York, NY, p 53-102

> Ambrose WGJ, Renaud PE (1995) Benthic response to water column productivity patterns: evidence for benthicpelagic coupling in the Northeast Water Polynya. J Geophys Res 100:4411-4421

Anderson MJ, Gorlay RN, Clarke KR (2008) PERMANOVA+ for PRIMER: guide for software and statistical methods. PRIMER-E, Plymouth

Archer D, Devol A (1992) Benthic oxygen fluxes on the Washington shelf and slope: A comparison of in situ microelectrode and chamber flux measurements. Limnol Oceanogr 37:614-629
Austen MC, McEvoy AJ (1997) The use of offshore meiobenthic communities in laboratory microcosm experiments: response to heavy metal contamination. J Exp Mar Biol Ecol 211:247-261

> Barlow MJ, Kingston PF (2001) Observation on the effects of barite on the gill tissues of the suspension feeder Cerastoderma edule (Linné) and the deposit feeder Macoma balthica (Linné). Mar Pollut Bull 42:71-76

Bechmann RK, Baussant T, Tandberg AH, Lowe D (2006) Clearance rate, growth, histopathology and biomarker responses in mussels and scallops exposed to suspended particles of water based drilling mud. In: Bechmann RK, Westerlund S, Baussant T, Taban IC, Pampanin DM, Smith M, Lowe D (eds) Impacts of drilling mud discharges on water column organisms and filter feeding bivalves. Report 2006/038, IRIS, p 39-64

Bellchambers LM, Richardson AMM (1995) The effect of substrate disturbance and burial depth on the venerid clam, Katelysis scalarina (Lamark, 1818). J Shellfish Res 14:41-44

Berge JA, Schaanning M, Bakke T, Sandøy K, Skeie GM, Ambrose WGJ (1986) A soft-bottom sublittoral mesocosm by the Oslofjord: description, performance and examples of application. Ophelia 26:37-54

Berner RA (1980) Early diagenesis: a theoretical approach. Princeton University Press, Princeton, NJ

Boudreau BP (1996) The diffusive tortuosity of fine-grained unlithified sediments. Geochim Cosmochim Acta 60: 3139-3142 doi: 10.1016/0016-7037(96)00158-5

> Braeckman U, Provoost P, Gribsholt B, Van Gansbeke D and others (2010) Role of macrofauna functional traits and density in biogeochemical fluxes and bioturbation. Mar Ecol Prog Ser 399:173-186

Bray JR, Curtis, JT (1957) An ordination of the upland forest communities of Southern Wisconsin. Ecol Monogr 27: 325-349

Buchanan JB (1971) Sediments. In: Holme NA, McIntyre AD (eds.) Methods for the study of marine benthos. IBP Handbook 16, Blackwell Scientific Publications, Oxford, p 30-52

Christie H (1985) Ecological monitoring strategy with special reference to a rocky subtidal programme. Mar Pollut Bull 16:232-235

Cranford PJ, Gordon DC Jr, Lee K, Armsworthy SL, Tremblay GH (1999) Chronic toxicity and physical disturbance effects of water- and oil-based drilling fluids and some major constituents on adult sea scallops (Placopecten magellanicus). Mar Environ Res 48:225-256

Currie DR, Isaacs LR (2005) Impact of exploratory offshore drilling on benthic communities in the Minerva gas field, Port Campbell. Australia. Mar Environ Res 59:217-233

> Daan R, Mulder M (1996) On the short-term and long-term impact of drilling activities in the Dutch sector of the North Sea. ICES J Mar Sci 53:1036-1044

> Ellingsen K (2002) Soft-sediment benthic biodiversity on the continental shelf in relation to environmental variability. Mar Ecol Prog Ser 232:15-27

> Etter RJ, Grassle JF (1992) Patterns of species diversity in the deep sea as a function of sediment particle size diversity. Nature 360:576-578

Fertl WH, Chilingar GV, Robertson JO Jr (2002) Chapter 6 Drilling parameters. In: Chilingar GV, Serebryakov VA, Robertson JO Jr (eds) Origin and prediction of abnormal formation pressures. Dev Petr Sci 50:151-167

> Gaston GR, Rakocinski CF, Brown SS, Cleveland CM (1998) 
Trophic structure in estuaries: response of macrobenthos to natural and contaminant gradients. Mar Freshw Res 49:833-846

Glud RN, Gundersen JK, Roy H, Jørgensen BB (2003) Seasonal dynamics of benthic $\mathrm{O}_{2}$ uptake in a semienclosed bay: importance of diffusion and faunal activity. Limnol Oceanogr 48:1265-1276

- Granberg ME, Selck H (2007) Effects of sediment organic matter quality on bioaccumulation, degradation, and distribution of pyrene in two macrofaunal species and their surrounding sediment. Mar Environ Res 64:313-335

Grasshoff K, Erhardt M, Kremling K (1983) Methods of seawater analysis, 2nd edn. Verlag Chemie, Weinheim

Gray JS (1974) Animal-sediment relationship. Oceanogr Mar Biol Annu Rev 12:223-261

- Gray JS (2002) Species richness of marine soft sediments. Mar Ecol Prog Ser 244:285-297

Gray JS, Elliott M (2009) Ecology of marine sediments. From science to management. 2nd edn. Oxford University Press, Oxford

Gray JS, Clarke KR, Warwick RM, Hobbs G (1990) Detection of initial effects of pollution on marine benthos: an example from the Ekofisk and Eldfisk oilfields, North Sea. Mar Ecol Prog Ser 66:285-299

Grebmeier JM, McRoy CP, Feder HM (1988) Pelagicbenthic coupling on the shelf of the northern Bering and Chukchi Seas. I. Food supply source and benthic biomass. Mar Ecol Prog Ser 48:57-67

Green AS, Chandler GT, Blood ER (1993) Aqueous-, porewater-, and sediment-phase cadmium: toxicity relationships for a meiobenthic copepod. Environ Toxicol Chem 12:1497-1506

Grung B, Brakstad F, Birkely SR (2005) NOEC field validation part II: the mowing window approach. ERMS report no. 14, MUST. www.sintef.no/Projectweb/ERMS/Reports/

> Gunnarsson JS, Schaanning MT, Hylland K, Sköld M, Eriksen DØ, Berge JA, Skei J (1996) Interactions between eutrophication and contaminants. III. Mobilization and bioaccumulation of benzo(a)pyrene from marine sediments. Mar Pollut Bull 33:80-89

Gunnarsson JS, Granberg ME, Nilsson HC, Rosenberg R, Hellman B (1999) Influence of sediment-organic matter quality on growth and polychlorobiphenyl bioavailability in Echinodermata (Amphiura filiformis). Environ Toxicol Chem 18:1534-1543

> Hulth S, Blackburn TH, Hall POJ (1994) Arctic sediments (Svalbard): consumption and microdistribution of oxygen. Mar Chem 46:293-316

Hyland L, Hardin D, Steinhauer M, Coats D, Green R, Neff J (1994) Environmental impact of offshore oil development on the outer continental shelf and slope off point Arguello, California. Mar Environ Res 37:195-229

> Jackson MJ, James R (1979) The influence of bait digging on cockle, Cerastoderma edule, population in North Norfolk. J Appl Ecol 16:671-679

- Kemp PF (1988) Acute toxicity of interstitial and particlebound cadmium to a marine infaunal copepod. Mar Environ Res 26:135-153

Kingston PF (1987) Field effects of platform discharges on benthic macrofauna. Philos Trans R Soc Lond B Biol Sci 316:545-565

Levene H (1960) Robust tests for equality of variances. In: Olkin I, Ghurye SG, Hoeffding W, Madow WG, Mann HB (eds) Contributions of probability and statistics: essays in honor of Harold Hotelling. Stanford University
Press, Stanford, CA, p 278-292

Li XZ, Li BQ, Wang HF, Wang JB and others (2009) Community structure of macrobenthos in coastal water off Rushan, southern Shandong Peninsula, and the relationships with environmental factors. Acta Oceanol Sin 28: 81-93

> Lohrer AM, Thrush SF, Gibbs MM (2004) Bioturbators enhance ecosystem function through complex biogeochemical interactions. Nature 431:1092-1095

> Lohrer AM, Halliday NJ, Thrush SF, Hewitt JE, Rodil IF (2010) Ecosystem functioning in a disturbance-recovery context: contribution of macrofauna to primary production and nutrient release on intertidal sandflats. J Exp Mar Biol Ecol 390:6-13

- Maloney J (1996) Influence of organic enrichment on the partitioning and bioavailability of cadmium in a microcosm study. Mar Ecol Prog Ser 144:147-161

Maurer D, Keck RT, Tinsman JC, Leathem WA (1982) Vertical migration and mortality of benthos in dredged material: Part III - Polychaeta. Mar Environ Res 6:49-68

Mermillod-Blondin F, Francois-Carcaillet F, Rosenberg R (2005) Biodiversity of benthic invertebrates and organic matter processing in shallow marine sediments: an experimental study. J Exp Mar Biol Ecol 315:187-209

Neff JM (2005) Composition, environmental fates, and biological effect of water based drilling muds and cuttings discharged to the marine environment: a synthesis and annotated bibliography. Prepared for Petroleum Environmental Research Forum (PERF) and American Petroleum Institute. Battelle, Duxbury, MA

Neff JM, Rabalais NN, Boesch DF (1987) Offshore oil and gas development activities potentially causing long-term environmental effects. In: Boesch DF, Rabalais NN (eds) Long term effects of offshore oil and gas development. Elsevier Applied Science Publishers, London, p 149-174

Netto SA, Fonseca G, Gallucci F (2010) Effects of drill cuttings discharges on meiofauna communities of a shelf break site in the southwest Atlantic. Environ Monit Assess 167:49-63

> Nizzoli D, Bartoli M, Cooper M, Welsh DT, Underwood GJC, Viaroli P (2007) Implications for oxygen, nutrient fluxes and denitrification rates during the early stage of sediment colonisation by the polychaete Nereis spp. in four estuaries. Estuar Coast Shelf Sci 75:125-134

> Norling K, Rosenberg R, Hulth S, Grémare A, Bonsdorff E (2007) Importance of functional biodiversity and speciesspecific traits of benthic fauna for ecosystem functions in marine sediment. Mar Ecol Prog Ser 332:11-23

Olsgard F, Gray JS (1995) A comprehensive analysis of the effects of offshore oil and gas exploration and production on the benthic communities of the Norwegian continental field. Mar Ecol Prog Ser 122:277-306

OSPAR Commission (2008) OSPAR List of Substances/ Preparations Used and Discharged Offshore which Are Considered to Pose Little or No Risk to the Environment (PLONOR), 2008 update. OSPAR report 2004-10E. www. klif.no/arbeidsomr/petroleum/dokumenter/plonor2008. pdf

Pesch CE (1979) Influence of three sediment types on copper toxicity to the polychaete Neanthes arenaceodentata. Mar Biol 52:237-245

Quijón PA, Kelly MC, Snelgrove PVR (2008) The role of sinking phytodetritus in structuring shallow-water benthic communities. J Exp Mar Biol Ecol 366:134-145

> Rasmussen H, Jørgensen BB (1992) Microelectrode studies 
of seasonal oxygen uptake in coastal sediment: role of molecular diffusion. Mar Ecol Prog Ser 81:289-303

Revsbech NP (1989) An oxygen microelectrode with a guard cathode. Limnol Oceanogr 34:472-474

Rhoads DC (1974) Organism-sediment relations on the muddy sea floor. Oceanogr Mar Biol Annu Rev 12: 263-300

Rye H, Furuholt E (2010) Validation of numerical model for simulation of drilling discharges to sea. SPE-paper 137348, Abu Dhabi International Petroleum Exhibition \& Conference, 1-4 November 2010

Schaanning M, Hylland K, Lichtenthaler R, Rygg B (1996) Biodegradation of Anco Green and Novaplus drilling muds on cuttings deposited in benthic chambers. Report no. OR-3475, Norwegian Institute for Water Research (NIVA), Oslo. http://rapp.niva.no/symfoni/RappArkiv3.nsf/ URL/C125730900417026C1256FB800533F65/\$FILE/3475_ 72dpi.pdf

Schaanning MT, Trannum HC, Øxnevad S, Carroll J, Bakke $\mathrm{T}$ (2008) Effects of drill cuttings on biogeochemical fluxes and macrobenthos of marine sediments. J Exp Mar Biol Ecol 361:49-57

Singsaas I, Rye H, Frost TK, Smit MGD and others (2008) Development of a risk-based environmental management tool for drilling discharges. Summary of a four-year project. Integr Environ Assess Manag 4:171-176

Smith SDA, Rule MJ (2001) The effects of dredge-spoil dumping on a shallow water soft-sediment community in the Solitary Islands marine Park, NSW, Australia. Mar Pollut Bull 42:1040-1048

Svensson JR, Lindegarth M, Pavia H (2010) Physical and biological disturbances interact differently with productivity: effects on floral and faunal richness. Ecology 91:

Editorial responsibility: Pei-Yuan Qian, Kowloon, Hong Kong SAR
3069-3080

> Swartz RC, Ditsworth GR, Scults DW, Lamberson JO (1986) Sediment toxicity to a marine infaunal amphipod: cadmium and its relation with sewage sludge. Mar Environ Res 18:133-153

Terlizzi A, Scuderi D, Fraschetti S, Anderson MJ (2005) Quantifying effects of pollution on biodiversity: a case study of highly diverse molluscan assemblages in the Mediterranean. Mar Biol 148:293-305

Thrush SF, Halliday J, Hewitt JE, Lohrer AM (2008) The effects of habitat loss, fragmentation, and community homogenization on resilience in estuaries. Ecol Appl 18: $12-21$

Tietjen JH (1980) Population structure and species distribution of free-living nematodes inhabiting sands of the New York Bight Apex. Estuar Coast Mar Sci 10:61-73

> Trannum HC, Olsgard F, Skei JM, Indrehus J, Øverås S, Eriksen J (2004) Effects of copper, cadmium and contaminated harbour sediments on recolonisation of softbottom communities. J Exp Mar Biol Ecol 310:87-114

Trannum HC, Nilsson HC, Schaanning MT, Øxnevad S (2010) Effects of sedimentation from water-based drill cuttings and natural sediment on benthic macrofaunal community structure and ecosystem processes. J Exp Mar Biol Ecol 383:111-121

Traunspurger W, Drews C (1996) Toxicity analysis of freshwater and marine sediment with meio- and macrobenthos organisms. Hydrobiol 328:215-261

Ugland KI, Bjørgesæter A, Bakke T, Fredheim B, Gray JS (2008) Assessment of environmental stress with a biological index based on opportunistic species. J Exp Mar Biol Ecol 366:169-174

Submitted: December 6, 2010; Accepted: August 8, 2011 Proofs received from author(s): November 18, 2011 